\title{
Genotype by Environment Interactions on Cotton Fiber Traits and Their Implications on Variety Recommendation
}

\author{
Vasileios Greveniotis (Corresponding author) \\ Technological Education Institute of Thessaly, \\ Department of Agricultural Technology, \\ 41110 Larissa, Greece \\ E-mail: vgreveni@mail.com \\ Evangelia Sioki \\ Hellenic Agricultural Organization - "Demeter", \\ National Center For Quality Control, \\ Classification \& Standardization of Cotton, \\ 1st km Karditsa-Mitropolis, \\ 43100 Karditsa, Greece.
}

Received: February 17, 2017

Accepted: April 5, 2017

Published: June 7, 2017

doi:10.5296/jas.v5i2.10762

URL: https://doi.org/10.5296/jas.v5i2.10762

\begin{abstract}
The objective of this study was to evaluate cotton fiber quality traits across diverse environments. This could lead to the selection of the best environment for cotton cultivations and the best adapted commercial cultivars. For this reason four main cotton regions were chosen as different environments: Thessaly, Thrace, Macedonia and Sterea Ellas. Five of the most commercial upland cotton cultivars (DP332, DP377, ST402, CELIA and ELSA) were used for evaluation of their fiber quality traits. Each cultivar was sown in 10 different fields (in order to exploit and evaluate different soil types) in each of the above mentioned regions and (in total) 200 fields were used in total. Four samples from each field were collected in order to analyze fiber quality traits: micronaire, maturity index (\%), fiber length as the upper half mean length $(\mathrm{mm})$, fiber strength (gram/tex), uniformity index $(\%)$, fiber elongation,
\end{abstract}


short fiber index, yellowness $(+b)$, reflectance index $(\mathrm{Rd})$.

Cultivation regions must also be selected in a way that they could promote fiber traits, in order to ensure the highest fiber quality. Cotton fiber quality traits were affected differently from environmental fluctuations, showing that the ranking of cultivars according to environmental fluctuations is important, if proper breeding methods should be applied. Each trait is affected differently by environmental fluctuations and requires precise knowledge of the degree of inheritance i.e., as to how much qualitative or quantitative is the trait, in order to choose and apply the proper breeding method.

Keywords: Gossypium hirsutum L., GxE interaction, fiber quality, main variability factor, cultivation regions

\section{Introduction}

Because of its broad adaptability (Hake and Kerby, 2006) and fiber traits, cotton (Gossypium hirsutum L.) is considered to be one of the most important industrial plants worldwide and this also applies for Greece, which is the 9th cotton export country (Cotton Incorporated, 2016). Quality traits of cotton commercial cultivars are of great importance for textile manufacturers (Bradow and Davidonis, 2000; Jost, 2005; Gregory et al., 2012). Fiber quality is a complex of various traits, such as fiber length, strength, uniformity etc. (Poehlman and Sleper, 1995) and thus it depends on both genetic and environmental factors that influence the plant's development (Bradow and Davidonis, 2000; Campbell and Jones, 2005; Basal et al., 2009a; Kothari et al., 2015).

Environmental factors have the potential of affecting the expression of many characteristics, especially quantitative traits in comparison to qualitative ones. To minimize environmental effects, breeders prefer to conduct experiments over multiple locations and years (as a tool) to ensure the best performance of potential cultivars (Bernardo, 2002). For many breeders, genotype by environment interaction $(\mathrm{GxE})$ is considered critical to ensure heritability through the passing breeding generations (Kang, 2002 and 2004; Campbell et al., 2012). Stability has been defined as the ability of a cultivar to show minimum interaction with the environment (Eberhart and Russell, 1966). In cotton breeding programs, genotype stability is an important objective for both quantitative and fiber qualitative traits (Geng et al., 1987).

The genetic effect $(\mathrm{G})$ along with the genotype-environment interaction (GE) was used in GGE biplot models, as a breeding tool that can describe visually mean performance and stability (Yan, 2001; Kang et al., 2005). The fast and easy identification of genotypes exhibiting high average yield and low GE interaction, thus stability, is considered critical for a breeding program (Cecarelli, 1989) and usually involves multi-location tests and subsequent GGE biplot analysis (Yan and Holland, 2010; Yan et al., 2011). GGE biplots can reveal the ideal genotype, a ranking of cultivars on the basis of yield and stability and ideal location for better performance of genotypes (Yan and Kang, 2003; Fan et al., 2007). Today, two types of biplot models are widely used: the previously described genotype/genotype-environment interaction GGE biplot (Yan and Kang, 2003) and the additive main effects and multiplicative interaction AMMI (Gauch, 1992), that combines 
principal components analysis and analysis of variance (Gauch and Zobel, 1997). The latter is more suitable for environment classification combined with genotype evaluation. Gauch and Zobel (1997) used the term of mega-environment as the separation of a cultivation area into different target zones. Environment classification to describe mega-environments was the result of successful implementation of the AMMI model.

Farm trials over the range of cropping environments are needed, to provide extensive agronomic and farmer advices, along with the necessary recommendation of the proper cultivars for each special environment. The purpose of this study was to evaluate fiber quality traits across diverse environments. This could lead to an environment selection for cotton cultivations and to a proposition of the best commercial cultivars.

\section{Materials and Methods}

Four main cotton regions in Greece were characterized as different environments: Thessaly, Thrace, Macedonia and Sterea Ellas. The differences in environmental conditions are presented in Figure 1, where the four regions showed different environmental patterns regarding monthly temperatures and rainfall for the year 2014. Environmental data of these regions have also been monitored for the previous five years (2009-2013), shown in Figure 2.
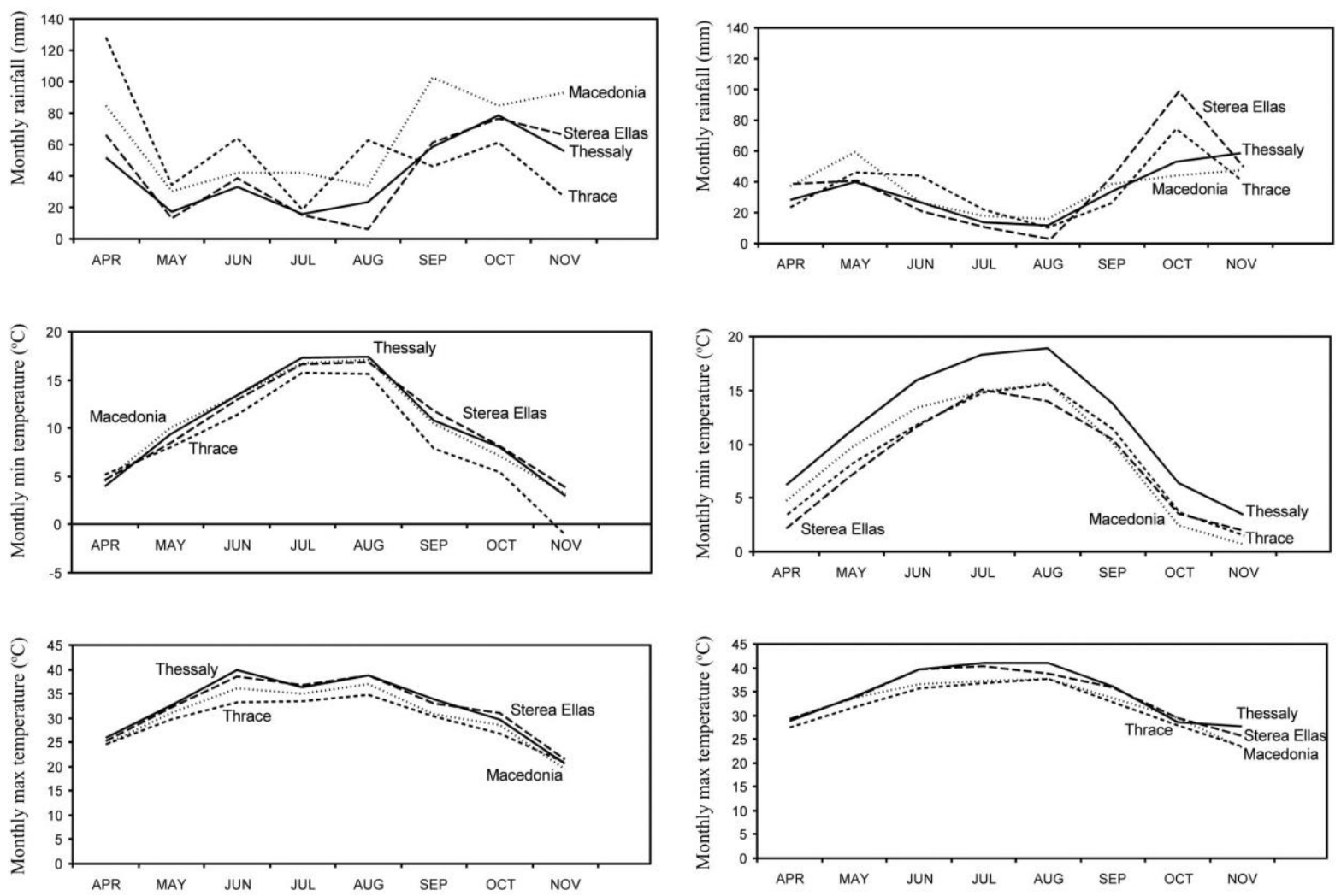

Figure 1. Environmental data (rainfall in $\mathrm{mm}$, maximum: max and minimum: min temperature in ${ }^{\circ} \mathrm{C}$ ) in each region for year 2014

Figure 2. Environmental data (rainfall in $\mathrm{mm}$, maximum: max and minimum: min temperature in ${ }^{\circ} \mathrm{C}$ ) in each region for years 2009-2013. 
The genetic material used consisted of five commercial upland cotton cultivars; i.e. cultivars DP332 and DP377 proprietary of Monsanto Co, ST402 proprietary of Pioneer Hi-Bred, CELIA and ELSA proprietary of Bayer Crop Science. These cultivars, varying in origin and maturity class, were selected for evaluation of their fiber quality traits in 2014. Ten fields in each of four regions were chosen for sowing each cultivar separately, in order to evaluate different soil types and environmental conditions. Thus, each cultivar was sown in 40 fields and 200 fields in total were used for all cultivars. Each plot area was greater than 1 ha. Rows spaced $96 \mathrm{~cm}$ apart and plant density was on average 15 plants per $\mathrm{m}^{-2}$. Crop management practices for each location were consistent with typical agronomic practices in the region and included full irrigation applied with sprinklers from mid-June until 20 days prior to harvest, spraying for pests as required and weed control by pre-planting herbicides.

Four samples from each field were collected to analyze fiber quality traits by High Volume Instrument (HVI). Samples consisted of 300 randomly handpicked bolls and total seed cotton weight was measured. Subsequently, samples were ginned on a laboratory ginning machine (Zellweger Uster Inc.) and lint percentage (\%) was calculated as the ratio of lint weight to the total seed cotton weight. Fiber quality traits were evaluated using a HVI at the accredited laboratory of National Center of Cotton, in Karditsa-Greece. Quality traits assessed in this study were micronaire, maturity index (\%), fiber length as the upper half mean length $(\mathrm{mm})$, fiber strength (gram/tex), uniformity index (\%), fiber elongation, short fiber index, yellowness $(+b)$, reflectance index $(\mathrm{Rd})$.

Statistics included factor analysis (ANOVA) of each trait (Steel and Torrie, 1980), performed separately for each individual evaluation trial and combined across locations. Sum of Squares have also been calculated as (\%) percentage of each factor, while means separation was based on Duncan's method (Steel and Torrie, 1980). For ANOVA, environments have been considered as the random factor, since a GGE biplot model indicated that cultivation conditions of cotton constitute a mega-environment with no repeatable patterns in Greece (Baxevanos et al., 2006), and genotypes as the fixed factor. The cultivar phenotypic variance $\left(\sigma_{p}^{2}\right)$ was partitioned to its respective components, cultivar genetic variance $\left(\sigma_{g}^{2}\right)$ and cultivar by environment interaction variance $\left(\sigma_{\text {ge }}^{2}\right)$ (McIntosh, 1983). The broad sense heritability estimation $(\mathrm{H})$ was calculated as $\sigma_{\mathrm{g}}^{2} / \sigma_{\mathrm{p}}^{2}$ ratio (Guillen-Portal et al., 2004). The GGE biplot and AMMI analyses for environment classification together with genotype evaluation were performed using the PB tools 1.4 software, provided by the IRRI. Adaptation maps were based on principal component analysis (PCA) for environments (Campbell and Jones, 2005), involving the two main fiber traits according to bibliography: fiber strength and length (May and Green, 1994). Correlations between fiber traits were performed according to Pearson coefficient (Steel and Torrie 1980).

\section{Results}

Table 1 presents the factor analyses for each fiber trait. Statistically significant differences were found for almost all traits, except for lint percentage (\%) and for the environment factor. Concerning the genotype factor, statistically significant differences were even greater. GxE interactions were found statistically significant for all fiber traits. 
Table 1. Factor analyses (ANOVA) for each fiber trait (lint percentage $\%$, micronaire, maturity index $\%$, fiber length in $\mathrm{mm}$, fiber strength, uniformity index $\%$, fiber elongation, short fiber index, yellowness, reflectance index).

\begin{tabular}{|c|c|c|c|c|c|c|}
\hline Source of variation & df & $\begin{array}{l}\text { Lint } \\
\text { Percentage } \\
(\%)\end{array}$ & Micronaire & $\begin{array}{l}\text { Maturity } \\
\text { index } \\
(\%)\end{array}$ & $\begin{array}{l}\text { Fiber } \\
\text { length } \\
(\mathrm{mm})\end{array}$ & $\begin{array}{l}\text { Uniformity } \\
\text { index } \\
(\%)\end{array}$ \\
\hline Environments (E) & 3 & $1.108^{\mathrm{ns}}$ & $0.290 *$ & $0.000 *$ & $10.241 * * *$ & $11.807 * * *$ \\
\hline Replications/E & 36 & 2.408 & 0.086 & 0.000 & 0.567 & 0.382 \\
\hline Genotypes (G) & 4 & $56.299 * * *$ & $1.615 * * *$ & $0.001 * * *$ & $14.689 * * *$ & $4.930 * * *$ \\
\hline $\mathrm{G} \times \mathrm{E}$ & 12 & $4.687 * *$ & $0.201 * * *$ & $0.000 *$ & $1.984 * * *$ & $1.280 * * *$ \\
\hline Polled Error & 144 & 2.026 & 0.062 & 0.000 & 0.402 & 0.396 \\
\hline $\mathrm{CV}(\%)$ & & 3.26 & 5.09 & 0.80 & 2.22 & 0.75 \\
\hline Source of variation & df & $\begin{array}{l}\text { Short fiber } \\
\text { index }\end{array}$ & $\begin{array}{l}\text { Fiber } \\
\text { strength } \\
\text { (g/tex) }\end{array}$ & $\begin{array}{l}\text { Fiber } \\
\text { elongation }\end{array}$ & $\begin{array}{l}\text { Reflectance } \\
\text { index } \\
(\mathrm{Rd})\end{array}$ & $\begin{array}{l}\text { Yellowness } \\
(+b)\end{array}$ \\
\hline Environments (E) & 3 & $11.120 * * *$ & $14.541 * * *$ & $3.291 * * *$ & $179.57 * * *$ & $1.992 * * *$ \\
\hline Replications/E & 36 & 0.305 & 0.767 & 0.252 & 6.804 & 0.126 \\
\hline Genotypes (G) & 4 & $6.999 * * *$ & $29.458 * * *$ & $25.967 * * *$ & $35.239 * * *$ & $5.442 * * *$ \\
\hline $\mathrm{G} \times \mathrm{E}$ & 12 & $1.065 * * *$ & $2.813 * * *$ & $0.515^{*}$ & $18.090 * * *$ & $0.864 * * *$ \\
\hline \multirow[t]{2}{*}{ Polled Error } & 144 & 0.306 & 0.519 & 0.227 & 3.931 & 0.178 \\
\hline & & 7.00 & 2.29 & 6.05 & 2.55 & 5.47 \\
\hline
\end{tabular}

*Significant at $\mathrm{p}<0.05 ; * *$ Significant at $\mathrm{p}<0.01 ; * * *$ Significant at $\mathrm{p}<0.001$.

Table 2 presents averages of Sum of Squares treatment partitioning (\%) for Genotype (G), Environment $(\mathrm{E})$ and interaction $(\mathrm{GxE})$. Table 2 shows that for the majority of fiber traits, Genotype variability $(\mathrm{G})$ had the highest contribution of the total variability, except for uniformity index, short fiber index and reflectance index. Genetic variability $\left(\sigma_{\mathrm{g}}^{2}\right)$ contributed 
the greatest part of phenotypic variability $\left(\sigma_{p}^{2}\right)$, resulting in high broad sense heritability values $(\mathrm{H} \%)$ for all traits (usually over 80 ), except for reflectance index, where $\mathrm{GxE}$ interaction was higher and $\sigma_{\text {ge }}^{2} / \sigma_{p}^{2}$ was found to be $40 \%$. For lint percentage genotypes contributed $79 \%$ of total variability, while for micronaire and maturity index this was found $66 \%$, for fiber length $52 \%$ and for uniformity index and $\mathrm{Rd}$ this was only $28 \%$ and $16 \%$ respectively (where environment had the largest contribution: $50 \%$ and $60 \%$ respectively). For fiber elongation, genotype effects were also significant (87\%). Short fiber index, fiber strength and yellowness showed 38,61 and 57\% genotype effects respectively.

Table 2. Averages of Sum of Squares treatment partitioning (\%) for Genotype (G),

Environment $(\mathrm{E})$ and interaction $(\mathrm{GxE})$, broad sense heritability $(\mathrm{H})$ and the heritability ratios $\left(\sigma_{\mathrm{ge}}^{2} / \sigma_{\mathrm{p}}^{2}, \sigma_{\mathrm{e}}^{2} / \sigma_{\mathrm{p}}^{2}\right)$.

\begin{tabular}{|c|c|c|c|c|c|}
\hline Traits & $\begin{array}{l}\text { Lint } \\
\text { Percentage }\end{array}$ & Micronaire & $\begin{array}{l}\text { Maturity } \\
\text { index }\end{array}$ & Fiber length & $\begin{array}{l}\text { Uniformity } \\
\text { index }\end{array}$ \\
\hline $\begin{array}{l}\text { Environments } \\
(\%)\end{array}$ & 2 & 9 & 17 & 27 & 50 \\
\hline $\begin{array}{l}\text { Genotypes } \\
(\%)\end{array}$ & 79 & 66 & 66 & 52 & 28 \\
\hline $\mathrm{G} \times \mathrm{E}(\%)$ & 19 & 25 & 17 & 21 & 22 \\
\hline $\mathrm{H}(\%)$ & 92 & 87 & 91 & 86 & 74 \\
\hline$\sigma_{g e}^{2} / \sigma_{p}^{2}(\%)$ & 5 & 9 & 4 & 11 & 18 \\
\hline$\sigma^{2}{ }_{e} / \sigma_{p}^{2}(\%)$ & 3 & 4 & 5 & 3 & 8 \\
\hline Traits & $\begin{array}{l}\text { Short fiber } \\
\text { index }\end{array}$ & $\begin{array}{l}\text { Fiber } \\
\text { strength }\end{array}$ & $\begin{array}{l}\text { Fiber } \\
\text { elongation }\end{array}$ & $\begin{array}{l}\text { Reflectance } \\
\text { index }(\mathrm{Rd})\end{array}$ & $\begin{array}{l}\text { Yellowness } \\
(+b)\end{array}$ \\
\hline $\begin{array}{l}\text { Environments } \\
(\%)\end{array}$ & 45 & 22 & 8 & 60 & 16 \\
\hline $\begin{array}{l}\text { Genotypes } \\
(\%)\end{array}$ & 38 & 61 & 87 & 16 & 57 \\
\hline Gx E (\%) & 17 & 17 & 5 & 24 & 27 \\
\hline $\mathrm{H}(\%)$ & 85 & 90 & 98 & 49 & 84 \\
\hline
\end{tabular}




\begin{tabular}{|l|l|l|l|l|l|}
\hline$\sigma_{\mathrm{ge}}^{2} / \sigma_{\mathrm{p}}^{2}(\%)$ & 11 & 8 & 1 & 40 & 13 \\
\hline$\sigma_{\mathrm{e}}^{2} / \sigma_{\mathrm{p}}^{2}(\%)$ & 4 & 2 & 1 & 11 & 3 \\
\hline
\end{tabular}

Tables 3 and 4, present means of all fiber traits (lint percentage $\%$, micronaire, maturity index $\%$, fiber length in $\mathrm{mm}$, fiber strength, uniformity index $\%$, fiber elongation, short fiber index, yellowness, reflectance index), for the five cultivars, from all four regions. Means of cultivars for lint percentage ranged from 41.98 to 44.78 , for micronaire from 4.633 to 5.177 , for maturity index from 0.861 to 0.872 , for fiber length from 27.873 to 29.208 , for uniformity index from 83.67 to 84.505 , for short fiber index from 7.53 to 8.59 , for fiber strength from 30.585 to 32.741 , for fiber elongation from 6.68 to 8.746 , for $\mathrm{Rd}$ from 76.522 to 79.115 and for yellowness from 7.274 to 8.176 .

Significant fluctuations were revealed for means within, as it was expected, because of the GxE interactions in table 1. In lint percentage, cultivars DP332, DP377 and ELSA showed the greatest values (over 44\%). For micronaire, ST402 and DP377 exhibited extremely high values. For maturity index, all cultivars showed satisfactory values over $86 \%$, even though there were statistically significant differences. For fiber length, CELIA and ELSA exhibited the greatest values (over $29 \mathrm{~mm}$ ). For uniformity index, all cultivars reached the satisfactory value of 85\%. For short fiber index, DP332 and DP377 showed the lowest values near or over $8 \%$. For fiber strength CELIA cultivar showed the best values, followed by ELSA. For fiber elongation, cultivars DP332, ST402 and ELSA showed the best values (over 8). For reflectance index and yellowness, CELIA exhibited the best values.

Table 3. Means of all fiber traits (lint percentage \%, micronaire, maturity index \%, fiber length in mm, fiber strength, uniformity index \%), for the five cultivars (DP332, DP377, ST402, CELIA and ELSA), across the four different regions (Thessaly, Thrace, Macedonia and Sterea Ellas).

\begin{tabular}{|c|c|c|c|c|c|c|}
\hline & \multicolumn{6}{|c|}{ Lint Percentage (\%) } \\
\hline & DP 332 & DP 377 & CELIA & ELSA & ST 402 & MEAN \\
\hline Thessaly & $44.98 \mathrm{a}$ & $43.90 \mathrm{a}$ & $42.70 \quad \mathrm{a}$ & 44.45 & $42.42 \quad \mathrm{a}$ & $43.50 \mathrm{a}$ \\
\hline Macedonia & $45.36 \quad \mathrm{a}$ & $45.01 \quad \mathrm{a}$ & $43.23 \mathrm{a}$ & $42.94 \mathrm{~b}$ & 42.20 & $43.75 \mathrm{a}$ \\
\hline Thrace & $44.43 \quad \mathrm{a}$ & $44.21 \mathrm{a}$ & $42.64 \quad \mathrm{a}$ & $45.02 \mathrm{a}$ & $40.81 \quad b$ & $43.42 \mathrm{a}$ \\
\hline Sterea Ellas & $44.35 \quad \mathrm{a}$ & $44.40 \quad \mathrm{a}$ & $42.54 \quad \mathrm{a}$ & $44.17 \quad \mathrm{a}$ & 42.50 & $43.59 \mathrm{a}$ \\
\hline Mean & $44.78 \mathrm{a}$ & $44.40 \mathrm{a}$ & $42.78 \mathrm{~b}$ & 44.15 & 41.98 & \\
\hline
\end{tabular}




\begin{tabular}{|c|c|c|c|c|c|c|}
\hline & \multicolumn{6}{|c|}{ Micronaire } \\
\hline Thessaly & $4.890 \mathrm{a}$ & $4.770 \mathrm{~b}$ & $4.574 \mathrm{bc}$ & $4.728 \mathrm{a}$ & $5.139 \mathrm{~b}$ & $4.870 \mathrm{ab}$ \\
\hline Macedonia & $4.789 \mathrm{a}$ & $5.128 \mathrm{a}$ & $4.879 \mathrm{a}$ & $4.844 \mathrm{a}$ & $5.069 \mathrm{~b}$ & $4.942 \mathrm{ab}$ \\
\hline Thrace & $4.876 \mathrm{a}$ & $5.125 \mathrm{a}$ & $4.380 \mathrm{c}$ & $4.869 \mathrm{a}$ & $5.098 \mathrm{ab}$ & $4.820 \mathrm{~b}$ \\
\hline Sterea Ellas & $5.006 \mathrm{a}$ & $4.960 \mathrm{ab}$ & $4.746 \mathrm{ab}$ & $4.895 \mathrm{a}$ & $5.401 \mathrm{a}$ & $4.992 \mathrm{a}$ \\
\hline \multirow[t]{2}{*}{ Mean } & $4.890 \mathrm{bc}$ & $4.996 \mathrm{~b}$ & $4.633 \mathrm{~d}$ & $4.834 \mathrm{c}$ & $5.177 \mathrm{a}$ & \\
\hline & \multicolumn{6}{|c|}{ Maturity index (\%) } \\
\hline Thessaly & $0.863 \mathrm{a}$ & $0.868 \mathrm{a}$ & $0.867 \mathrm{~b}$ & $0.863 \mathrm{~b}$ & $0.871 \mathrm{a}$ & $0.870 \mathrm{a}$ \\
\hline Macedonia & $0.858 \mathrm{~b}$ & $0.875 \mathrm{a}$ & $0.875 \mathrm{a}$ & $0.865 \mathrm{~b}$ & $0.869 \mathrm{a}$ & $0.868 \mathrm{~b}$ \\
\hline Thrace & $0.857 \mathrm{~b}$ & $0.873 \mathrm{a}$ & $0.862 \mathrm{c}$ & $0.859 \mathrm{c}$ & $0.867 \mathrm{a}$ & $0.866 \mathrm{c}$ \\
\hline Sterea Ellas & $0.865 \mathrm{a}$ & $0.871 \mathrm{a}$ & $0.873 \mathrm{a}$ & $0.868 \mathrm{a}$ & $0.874 \mathrm{a}$ & $0.864 \mathrm{~d}$ \\
\hline \multirow[t]{2}{*}{ Mean } & $0.861 \mathrm{~d}$ & $0.872 \mathrm{a}$ & $0.869 \mathrm{~b}$ & $0.864 \mathrm{c}$ & $0.870 \mathrm{~b}$ & \\
\hline & \multicolumn{6}{|c|}{ Fiber length (mm) } \\
\hline Thessaly & $27.818 \mathrm{a}$ & $28.330 \mathrm{a}$ & $28.686 \mathrm{~b}$ & $28.626 \mathrm{~b}$ & $28.311 \mathrm{~b}$ & $28.354 \mathrm{bc}$ \\
\hline Macedonia & $27.683 \mathrm{a}$ & $28.178 \mathrm{a}$ & $28.810 \mathrm{~b}$ & $29.862 \mathrm{a}$ & $28.761 \mathrm{~b}$ & $28.659 \mathrm{~b}$ \\
\hline Thrace & $28.220 \mathrm{a}$ & $28.816 \mathrm{a}$ & $29.927 \mathrm{a}$ & $29.497 \mathrm{a}$ & $29.590 \mathrm{a}$ & $29.210 \mathrm{a}$ \\
\hline Sterea Ellas & $27.771 \mathrm{a}$ & $27.241 \mathrm{~b}$ & $29.139 \mathrm{~b}$ & $28.815 \mathrm{~b}$ & $27.651 \mathrm{c}$ & $28.178 \mathrm{c}$ \\
\hline \multirow[t]{2}{*}{ Mean } & $27.873 \mathrm{c}$ & $28.141 \mathrm{c}$ & $29.208 \mathrm{a}$ & $29.200 \mathrm{a}$ & $28.578 \mathrm{~b}$ & \\
\hline & \multicolumn{6}{|c|}{ Uniformity index (\%) } \\
\hline Thessaly & $83.792 \mathrm{a}$ & $83.612 \mathrm{~b}$ & $83.877 \mathrm{~b}$ & $83.730 \mathrm{c}$ & $83.998 \mathrm{bc}$ & $83.802 \mathrm{c}$ \\
\hline Macedonia & $84.218 \mathrm{a}$ & $83.891 \mathrm{~b}$ & $84.423 \mathrm{ab}$ & $85.119 \mathrm{a}$ & $84.470 \mathrm{~b}$ & $84.424 \mathrm{~b}$ \\
\hline
\end{tabular}




\begin{tabular}{|l|l|l|l|l|l|l|}
\hline Thrace & $84.494 \mathrm{a}$ & $84.507 \mathrm{a}$ & $84.899 \mathrm{a}$ & $84.900 \mathrm{a}$ & $85.105 \mathrm{a}$ & $84.781 \mathrm{a}$ \\
\hline Sterea Ellas & $83.614 \mathrm{a}$ & $82.671 \mathrm{c}$ & $84.489 \mathrm{a}$ & $84.270 \mathrm{~b}$ & $83.744 \mathrm{c}$ & $83.797 \mathrm{c}$ \\
\hline Mean & $84.029 \mathrm{~b}$ & $83.670 \mathrm{c}$ & $84.472 \mathrm{a}$ & $84.505 \mathrm{a}$ & $84.329 \mathrm{a}$ & \\
\hline
\end{tabular}

*Values followed by the same letter are not significantly different at alpha $=0.05$ according to Duncan's multiple range test.

Table 4. Means of all fiber traits (fiber elongation, short fiber index, yellowness, reflectance index), for the five cultivars (DP332, DP377, ST402, CELIA and ELSA), across four different regions (Thessaly, Thrace, Macedonia and Sterea Ellas).

\begin{tabular}{|c|c|c|c|c|c|c|}
\hline & \multicolumn{6}{|c|}{ Short fiber index } \\
\hline Thessaly & $8.335 \mathrm{a}$ & $8.650 \mathrm{a}$ & $8.353 \mathrm{a}$ & $8.172 \mathrm{a}$ & $7.811 \mathrm{~b}$ & $8.264 \mathrm{a}$ \\
\hline Macedonia & $7.670 \mathrm{~b}$ & $8.423 \mathrm{~b}$ & $7.759 \mathrm{~b}$ & $6.969 \mathrm{c}$ & $7.545 b$ & $7.673 \mathrm{~b}$ \\
\hline Thrace & $7.505 \mathrm{~b}$ & $7.734 \mathrm{c}$ & $7.337 \mathrm{~b}$ & $7.197 \mathrm{c}$ & $6.976 \mathrm{c}$ & $7.350 \mathrm{c}$ \\
\hline Sterea Ellas & $8.403 \mathrm{a}$ & $9.551 \mathrm{a}$ & $7.789 \mathrm{~b}$ & $7.780 \mathrm{~b}$ & $8.252 \mathrm{a}$ & $8.325 \mathrm{a}$ \\
\hline \multirow[t]{2}{*}{ Mean } & $7.978 \mathrm{~b}$ & $8.590 \mathrm{a}$ & $7.772 \mathrm{bc}$ & $7.530 \mathrm{c}$ & $7.646 \mathrm{c}$ & \\
\hline & \multicolumn{6}{|c|}{ Fiber strength (g/tex) } \\
\hline Thessaly & $30.727 \mathrm{~b}$ & $30.476 \mathrm{~b}$ & $32.095 \mathrm{a}$ & $31.082 \mathrm{~b}$ & $30.626 \mathrm{~b}$ & $31.001 \mathrm{~b}$ \\
\hline Macedonia & $32.118 \mathrm{a}$ & $31.015 \mathrm{ab}$ & $32.882 \mathrm{a}$ & $32.013 \mathrm{a}$ & $30.939 \mathrm{~b}$ & $31.793 \mathrm{a}$ \\
\hline Thrace & $32.007 \mathrm{a}$ & $31.760 \mathrm{a}$ & $32.935 \mathrm{a}$ & $31.900 \mathrm{a}$ & $31.459 \mathrm{a}$ & $32.012 \mathrm{a}$ \\
\hline Sterea Ellas & $30.725 \mathrm{~b}$ & $29.089 \mathrm{c}$ & $32.693 \mathrm{a}$ & $31.875 \mathrm{a}$ & $30.074 \mathrm{c}$ & $30.963 b$ \\
\hline \multirow[t]{2}{*}{ Mean } & $31.394 \mathrm{c}$ & $30.585 \mathrm{~d}$ & $32.741 \mathrm{a}$ & $31.717 \mathrm{~b}$ & $30.775 \mathrm{~d}$ & \\
\hline & \multicolumn{6}{|c|}{ Fiber elongation } \\
\hline Thessaly & $8.444 \mathrm{~b}$ & $7.451 \mathrm{a}$ & $6.695 \mathrm{a}$ & $7.933 \mathrm{~b}$ & $8.110 \mathrm{~b}$ & $7.727 \mathrm{~b}$ \\
\hline Macedonia & $8.879 \mathrm{ab}$ & $7.209 \mathrm{a}$ & $6.632 \mathrm{a}$ & $7.809 \mathrm{~b}$ & $8.213 \mathrm{ab}$ & $7.748 \mathrm{~b}$ \\
\hline
\end{tabular}




\section{Macrothink}

\begin{tabular}{|l|l|l|l|l|l|l|l|}
\hline Thrace & $9.254 \mathrm{a}$ & $7.784 \mathrm{a}$ & $6.885 \mathrm{a}$ & $8.876 \mathrm{a}$ & $8.497 \mathrm{a}$ & $8.259 \mathrm{a}$ \\
\hline Sterea Ellas & $8.409 \mathrm{~b}$ & $7.551 \mathrm{a}$ & $6.708 \mathrm{a}$ & $7.875 \mathrm{~b}$ & $8.491 \mathrm{a}$ & $7.766 \mathrm{~b}$ \\
\hline Mean & $8.746 \mathrm{a}$ & $7.499 \mathrm{c}$ & $6.680 \mathrm{~d}$ & $8.123 \mathrm{~b}$ & $8.328 \mathrm{~b}$ & \\
\hline & Reflectance index (Rd) & \multicolumn{5}{|l}{} \\
\hline Thessaly & $77.265 \mathrm{~b}$ & $79.623 \mathrm{~b}$ & $77.689 \mathrm{~b}$ & $76.200 \mathrm{~b}$ & $76.493 \mathrm{~b}$ & $77.454 \mathrm{~b}$ \\
\hline Macedonia & $76.878 \mathrm{~b}$ & $77.745 \mathrm{c}$ & $77.574 \mathrm{~b}$ & $77.237 \mathrm{~b}$ & $74.742 \mathrm{c}$ & $76.835 \mathrm{~b}$ \\
\hline Thrace & $80.736 \mathrm{a}$ & $81.445 \mathrm{a}$ & $81.943 \mathrm{a}$ & $80.639 \mathrm{a}$ & $78.527 \mathrm{a}$ & $80.658 \mathrm{a}$ \\
\hline Sterea Ellas & $75.671 \mathrm{~b}$ & $73.957 \mathrm{~d}$ & $78.933 \mathrm{~b}$ & $77.512 \mathrm{~b}$ & $76.328 \mathrm{~b}$ & $76.544 \mathrm{~b}$ \\
\hline Mean & $77.638 \mathrm{~b}$ & $78.193 \mathrm{~b}$ & $79.115 \mathrm{a}$ & $77.897 \mathrm{~b}$ & $76.522 \mathrm{c}$ & \\
\hline Thrace & $7.719 \mathrm{~b}$ & $7.255 \mathrm{~b}$ & $7.262 \mathrm{a}$ & $7.153 \mathrm{~b}$ & $7.938 \mathrm{~b}$ & $7.465 \mathrm{a}$ \\
\hline Sterea Ellas & $8.502 \mathrm{a}$ & $8.069 \mathrm{a}$ & $7.545 \mathrm{a}$ & $7.503 \mathrm{~b}$ & $8.207 \mathrm{ab}$ & $7.950 \mathrm{a}$ \\
\hline Mean & $8.014 \mathrm{a}$ & $7.624 \mathrm{~b}$ & $7.274 \mathrm{c}$ & $7.516 \mathrm{~b}$ & $8.176 \mathrm{a}$ & \multicolumn{1}{|l}{} \\
\hline Mellowness (+b) & $7.927 \mathrm{~b}$ & $7.791 \mathrm{a}$ & $7.450 \mathrm{a}$ & $7.455 \mathrm{~b}$ & $7.918 \mathrm{~b}$ & $7.708 \mathrm{~b}$ \\
\hline & $7.907 \mathrm{~b}$ & $7.381 \mathrm{~b}$ & $6.911 \mathrm{~b}$ & $7.954 \mathrm{a}$ & $8.640 \mathrm{a}$ & $7.759 \mathrm{~b}$ \\
\hline
\end{tabular}

*Values followed by the same letter are not significantly different at alpha $=0.05$

$$
\text { according to Duncan's multiple range test. }
$$

In table 5, fiber length was significantly and positively highly correlated with uniformity index (0.74), but negatively highly correlated with short fiber index (-0.70). Also highly positive correlated with fiber strength (0.59). Significant high negative correlation was detected between uniformity index and short fiber index (-0.93), but positive with fiber strength (0.62). Significant high negative correlation was detected between fiber strength and short fiber index (-0.60). Maturity and micronaire were highly positive correlated (0.65). Many other correlations were found positive or negative significant.

May and Green (1994) suggested that fiber length and strength are the two main factors affecting fiber quality, for both cotton production and textile industry. For this reason, we 
present (and analyze) biplots for these main fiber traits.

Table 5. Coefficients of correlation between the traits: lint percentage $\%$, micronaire, maturity index $\%$, fiber length in $\mathrm{mm}$, fiber strength, uniformity index $\%$, fiber elongation, short fiber index, yellowness, reflectance index

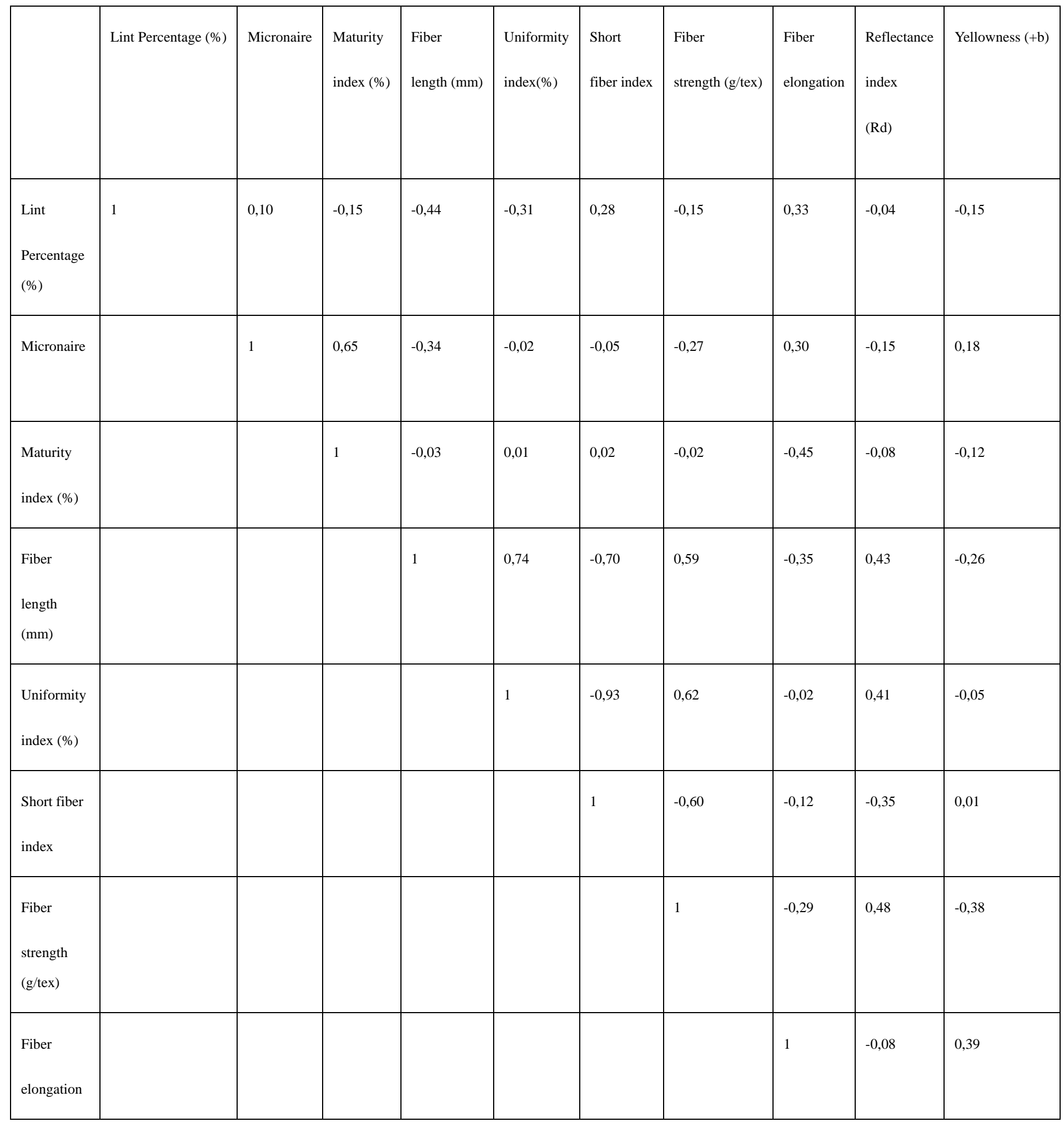




\begin{tabular}{|l|l|l|l|l|l|l|l|l|l|l|}
\hline $\begin{array}{l}\text { Reflectance } \\
\text { index (Rd) }\end{array}$ & & & & & & & & & & $-0,33$ \\
\hline $\begin{array}{l}\text { Yellowness } \\
(+b)\end{array}$ & & & & & & & & & & \\
\hline
\end{tabular}

Values in bold indicate that the correlation is significant at the 0.05 probability level

Figure 3 refers to fiber length and shows the adaptation map of the four environments for the five genotypes and the genotype main effect and $\mathrm{GxE}$ interaction in biplots. The adaptation map shows that E2 environment (Sterea Ellas) is very different in comparison to the other three environments which are grouped together at the higher end of the graph, with E4 being the most stable (corresponds to Thrace). G1 and G2 genotype (corresponding to CELIA and ELSA) are the most favorable genotypes for the fiber trait across all environments. G2 genotype (corresponds to ELSA) is the most stable. The same is apparent in the AMMI biplots. The GGE biplots shows that G2 genotype (corresponds to ELSA) reached the ideal one for the certain fiber trait in the environments used, with E4 (corresponds to Thrace) being better for promotion of the high capacity of the cultivars for the certain fiber trait. 

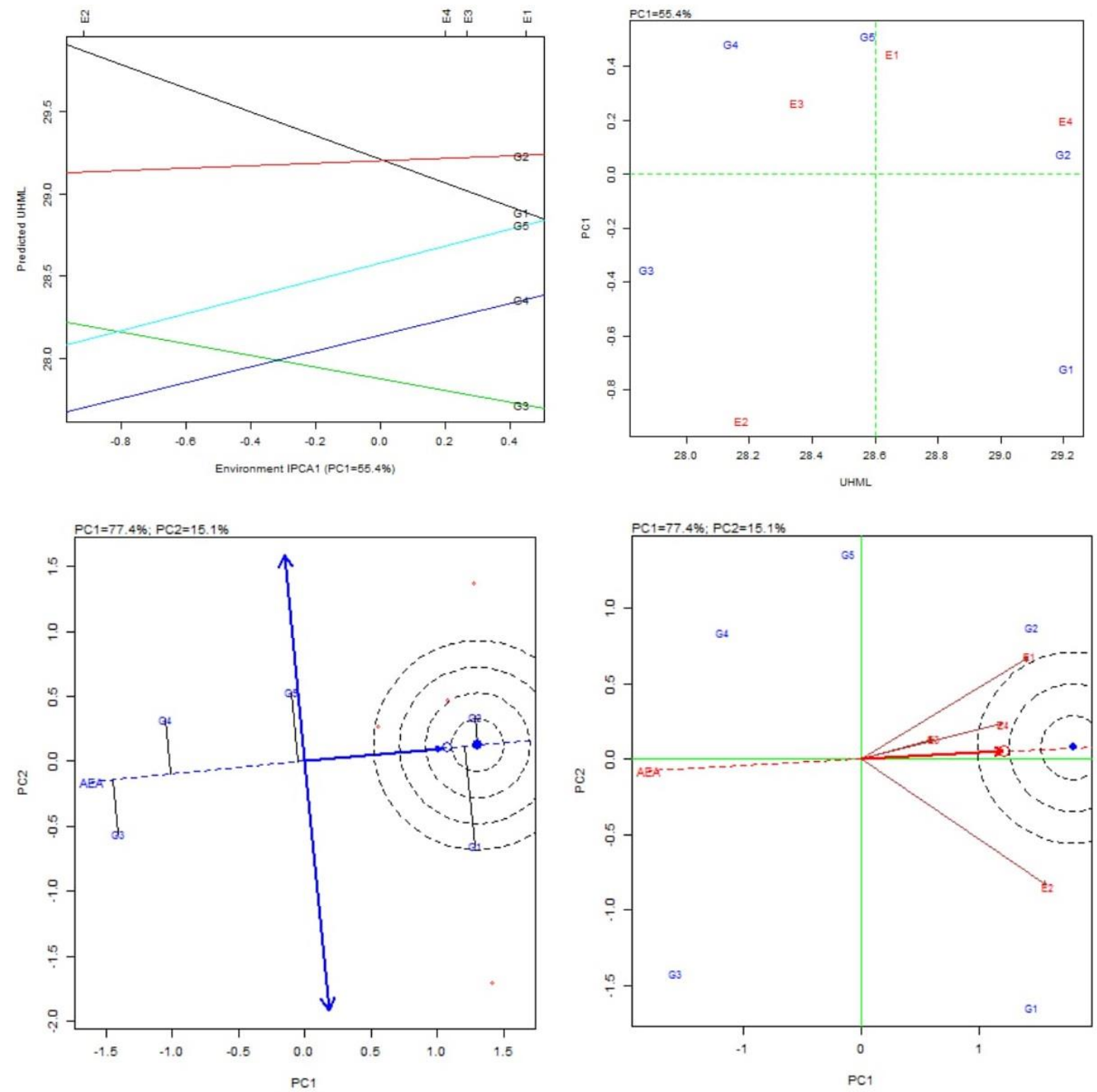

Figure 3. Adaptation map principal component analysis, AMMI biplots, genotype main effect and GxE interaction in GGE biplots and region (environment) main effect and GxE interaction biplots, for fiber length of the five cultivars (G1:CELIA, G2:ELSA, G3:DP332, G4:DP377 and G5:ST402) and the four different regions (E1:Macedonia, E2:Sterea Ellas, E3:Thessaly and E4:Thrace)

Figure 4 refers to fiber strength and presents the adaptation map of the four environments for the five genotypes and the genotype main effect and $\mathrm{GxE}$ interaction in biplots. The adaptation map shows that E2 environment (Sterea Ellas) is very different from the other three environments which are grouped together at the higher end of the graph, with E1 being the most stable (corresponds to Macedonia). G1 and G2 genotype (corresponds to CELIA and ELSA) are the most favorable genotypes for the certain trait across all environments. G3 and G5 genotypes (corresponds to DP332 and ST402) are the most stable. The same is apparent in the AMMI biplots. The GGE biplots shows that G1 genotype (corresponds to CELIA) satisfactory reached the ideal one for the certain fiber trait in the environments used, with E2 
(corresponds to Sterea Ellas) being better for promotion of the high capacity of the cultivars for the certain fiber trait.
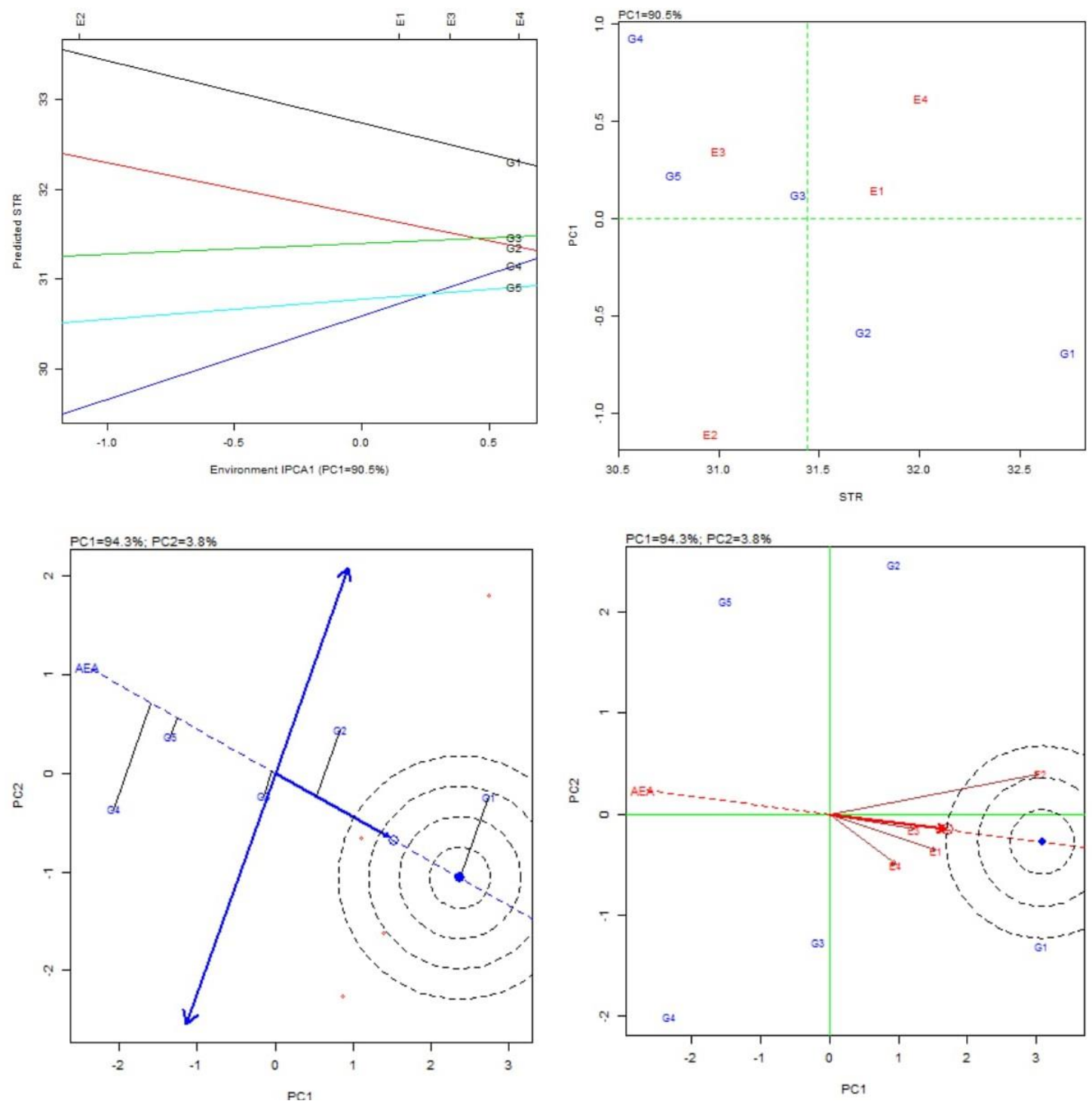

Figure 4. Adaptation map principal component analysis, AMMI biplots, genotype main effect and GxE interaction in GGE biplots and region (environment) main effect and GxE interaction biplots, for fiber strength of the five cultivars (G1:CELIA, G2:ELSA, G3:DP332, G4:DP377 and G5:ST402) and the four different regions (E1:Macedonia, E2:Sterea Ellas, E3:Thessaly and E4:Thrace)

\section{Discussion}

High fiber quality is essential for textile industry because it affects the quality of final products and the processing performance, with impact on processing cost and branding/marketing of the products (Basal et al., 2009a). 
In cotton, the effect of GxE varies among fiber traits, which means that certain fiber traits are more sensitive to environmental changes than others. The portion of sum of squares due to GxE in 12 environments for eight upland cultivars was found $8 \%, 20 \%, 8 \%, 8 \%, 24 \%, 9 \%$ and $3 \%$ for lint yield, lint percent, fiber length, strength, uniformity index, micronaire, and elongation, respectively (Campbell and Jones, 2005). In our study, statistically significant differences were found for almost all traits except for lint percentage for the factor environment. This indicates that lint percentage is mainly a genetically-controlled trait, as it is also evident from sum of squares proportion. Campbell and Jones (2005) also found that $57 \%$ of variability is genetically defined (in our study it is $79 \%$ ). The same was found by Blanche et al., (2006), Baxevanos et al. (2013), Snider et al. (2013). Some other researchers noted that environment is the main factor influencing the expression of lint percentage (Kerby et al., 2000; Meredith, 2003; Campbell et al., 2012; Meredith et al., 2012). Based on the results obtained from our study, the factor genotypes showed the greater statistically significant differences for all fiber traits. Combination of tables 1 and 2, also revealed that genotype variability contributed the greatest proportion, except for uniformity index, short fiber index and reflectance index. In our study uniformity seems to be affected by environmental conditions (50\%) and this is in agreement with the findings of Campbell and Jones (2005), Snider et al., (2013), while Baxevanos et al. (2013) showed that GxE interactions affect uniformity of cultivars across environments. We found that short fiber index and reflectance index are also influenced by environmental conditions (45 and 60\% respectively) and the same was depicted by Baxevanos et al. (2013). Genotype effect contribution vary from 52 (fiber length) to $87 \%$ (fiber strength) for the rest of fiber traits. Our findings are not always in agreement with other researchers (Kerby et al., 2000; Meredith, 2003; Cambell and Jones, 2005; Campbell et al., 2012; Meredith et al., 2012; Baxevanos et al., 2013; Snider et al., 2013). The relative size of Genotype effects to GxE interactions seems to be of great importance for estimating the effects on various traits (Yan and Kang, 2003).

Summarizing, genotype variability (G) contributed the greatest proportion, except for uniformity index, short fiber index and reflectance index. Additionally, genetic variability $\left(\sigma_{\mathrm{g}}^{2}\right)$ could explain the greatest part of phenotypic variability $\left(\sigma_{\mathrm{p}}^{2}\right)$, resulting in high broad sense heritability values $(\mathrm{H} \%)$ for all traits, except for reflectance index, where $\mathrm{GxE}$ interaction was found extremely high. Baxevanos et al. (2006 and 2008) had similar results, except for the extreme value for reflectance index found in our study. In addition, some very low values near the unit may indicate a relative homogeneous environment of evaluation, according to Baxevanos et al. (2006). High broad sense heritability indicates that multi-location evaluation may be successful for identifying superior genotypes.

Two cultivars exhibited satisfactory performance in various fiber traits, but significant fluctuations were revealed for means within, as it was expected because of the strong GxE interactions. For micronaire, cultivar ELSA showed the greater stability across environments. For maturity index, cultivar ST402 showed the greater stability across environments. For fiber length, cultivar DP332 showed the greater stability across environments. For uniformity index, cultivar DP332 showed the greater stability across environments. For fiber strength and fiber elongation, cultivar CELIA showed the greater stability across environments and, 
for the later trait, this was also found in cultivar DP377.

No correlation was revealed by our data set between lint percentage and micronaire, but positive with fiber elongation, short fiber index and negative with fiber length, uniformity index, fiber strength and yellowness. Karademir et al., 2010 reported that ginning percentage was significantly and positively correlated with micronaire, fiber elongation and fiber uniformity, but negatively correlated with fiber length and fiber strength. Ulloa and Meredith (2000) also reported a strongly negative connection between lint percentage and fiber strength. Lint percentage seems to be negatively affected by fiber strength and fiber length. In our study fiber strength was positively correlated with fiber length and uniformity and negatively with lint percentage, micronaire, short fiber and reflectance indices, revealing that cultivars with longer and uniform fibers exhibit also fiber strength. Fiber length was reported positively correlated with fiber strength, but negatively correlated with micronaire and fiber elongation (Karademir et al., 2010). Other researchers also reported similar results (Ulloa and Meredith, 2000; Azhar and Naeem, 2008; Asif et al., 2008; Basal et al., 2009b). Mei et al. (2004) reported insignificant correlation between fiber length and fiber elongation. Positive correlation between fiber length and fiber strength and uniformity indicated that three of the most important fiber quality traits (fiber length, fiber strength and uniformity) can be improved simultaneously.

Short fiber index showed highly negative correlations with fiber length and uniformity revealing that breeding efforts trying to minimize short fiber may lead to longer fibers with increased uniformity. Fiber elongation was found positively correlated with lint percentage, micronaire and yellowness, but negatively correlated with maturity index, fiber length and strength. Micronaire, although positively correlated with maturity, fiber elongation and yellowness, exhibited also negative correlations with fiber length, strength and reflectance index. These results showed that the all traits cannot be improved simultaneously. Yellowness and reflectance index showed a negative correlation, leading to the reasonable conclusion that these two traits are describing the same characteristic but in an opposed way. Many other correlations were found non-significant.

Location test prior to evaluating varieties seems to be of great importance (Baxevanos et al., 2008). New tools, like GGE biplots, allow us to estimate genotype and environment effects and as well as GxE interaction (Yan and Kang, 2003). GGE biplots allow the identification of the ideal genotype and the ideal environment-region in a graphical way (Yan, 2001).

May and Green (1994) consider that quality of fiber depends mainly on two main fiber traits: strength and length. Fiber strength and length are also considered very important traits by many other researchers (Sequeira et al., 1994; Bradow and Davidonis, 2000; Jost, 2005; Zhao, 2013). In our study, the adaptation map for fiber length showed that E2 environment (Sterea Ellas) is very different and rather unstable and unfavorable in comparison to the other three environments, with E4 (corresponds to Thrace)being the most stable, maybe because of its special environmental data. G1 and G2 genotypes (correspond to CELIA and ELSA respectively) are the most favorable genotypes, with significant stability for the certain trait across all environments. Apparently, breeding methods for these cultivars produced suitable 
genotypes for the certain trait in the Greek environments, accompanied by suitable cultural practices in Greece, as it was found in other cases (Bauer et al., 1993; Davidonis et al., 1996; Patsiali et al., 2014).

The adaptation map for fiber strength showed that E2 environment (Sterea Ellas) is very different in comparison to the other three environments, with E1 being the most stable (corresponds to Macedonia). Once again, G1 and G2 genotype (corresponds to CELIA and ELSA) are the most favorable genotypes for the certain trait across all environments. G3 and G5 genotypes (corresponds to DP332 and ST402) were the most stable. The same is apparent in the AMMI biplots for both fiber length and strength, indicating the resemblance of the methods used to define stable genotypes and environments. Macedonia and Thrace may be the best environments for cotton cultivation, due to favorable and stable performance of cultivars used in these areas. Always the growing environment affects cotton fiber quality, but main fiber traits such as length, strength and elongation are high heritable and depend on the proper genotype cultivation (Smith et al., 2010; Campbell et al., 2012; Long et al., 2013; Kothari et al., 2015).

GGE biplots confirm that great fluctuations of fiber traits exist in relation to genotype or the environment. According to Yan and Kang (2003) the ideal genotype is easily defined by GGE biplots. In our paper the GGE biplots showed that G2 genotype (corresponds to ELSA) reached the ideal one for fiber length in the environments used, with E4 region (corresponds to Thrace) being better for promotion of the capacity of the cultivars. Additionally, the GGE biplots showed that G1 genotype (corresponds to CELIA) satisfactory reached the ideal one for fiber strength in the environments used, with E2 (corresponds to Sterea Ellas) being better for promotion of the capacity of the cultivars for the certain fiber trait. The ideal environments that can promote main fiber quality traits seems to be Thrace and Sterea Ellas, and ELSA with CELIA seems to be more suitable cultivars for Greek mega-environment, for the certain year of experimentation, according to the remarks and assumptions of Baxevanos et al. (2007).

\section{Conclusions}

Production areas affect differently cotton quality traits, meaning that locations may be selected in such way that most effectively differentiate cultivars in relation to cotton fiber quality. Additionally, the cultivation regions must be also selected to promote fiber traits, in order to ensure highest fiber quality.

Cotton fiber quality traits are affected differently from environmental fluctuations, meaning that ranking of cultivars according to environmental fluctuations is important, if the proper breeding methods should be applied. Also, this is of great importance for the agronomist who has to recommend the proper cultivars for certain cultivation areas.

Each trait is affected differently by environmental fluctuations and requires precise knowledge of the degree of inheritance i.e., as to how much qualitative or quantitative is the trait in order to choose and apply the proper breeding method.

Some highly correlated and important traits can be improved simultaneously. 


\section{Acknowledgement}

Research is part of the action "Research \& Technology Development Innovation Projects AgroETAK", MIS 453350, in the framework of O.P. "Human Resources Development", co-funded by ESF and National funds (NSRF 2007-2014), coordinated by Hellenic Agricultural Organization "DEMETER".

\section{References}

Asif, M., Mirza J. I., \& Zafar Y. (2008). Genetic analysis for fiber quality traits of some cotton genotypes. Pakistan Journal of Botany, 40(3),1209-1215.

Azhar, F. M., \& Naeem, M. (2008). Assessment of Cotton (Gossypium hirsutum) Germplasm for Combining Abilities in Fiber Traits. Journal of Agriculture and Social Sciences, 4, 129-131.

Basal, H., Dagdelen, N., Unay A., \& Yilmaz, E. (2009a). Effects of deficit drip irrigation ratios on cotton (Gossypium hirsutum L.) yield and fibre quality. Journal of Agronomy \&. Crop Science, 195, 19-29. http://dx.doi.org/10.1111/j.1439-037X.2008.00340.x.

Basal, H., Unay, A., Canavar, O., \& Yavas, I. (2009b). Combining ability for fiber quality parameters and within-boll yield component in intraspesific and interspesific cotton populations. Spanish Journal of Agricultural Research, 7(2), 364-374.

Bauer, P. J., Camberato, J. J., \& Roach, S. H. (1993). Cotton yield and fiber quality responses to green manures and nitrogen. Agronomy Journal, 85, 1019-1023.

http://dx.doi.org/10.2134/agronj1993.000219620085000500012x.

Baxevanos, D., Goulas, C., Rossi, J., \& Braojos, E. (2008). Separation of cotton cultivar testing sites based on representativeness and discriminating ability using GGE biplots. Agronomy Journal, 100, 1230-1236. http://dx.doi.org/10.2134/agronj2007.0363.

Baxevanos, D., Goulas, C., Tzortzios, S., \& Mavromatis, A. (2006). Grouping Greek cotton (Gossypium hirsutum L.) trial locations into megaenvironmets. Agricultural Research, 29(2), 35-48 (in Greek with English summary).

Baxevanos, D., Goulas, C., Tzortzios, S. \& Mavromatis, A. (2007). Identification of cotton (Gossypium hirsutum L.) testing sites representative of the major Greek cotton region. Agricultural Research, 30(1), 35-46 (in Greek with English summary).

Baxevanos, D., Tsialtas, I. T., \& Goulas, C. (2013). Repeatability and stability analysis for fiber traits in upland cotton (Gossypium hirsutum L.). Australian Journal of Crop Sciience, 7(10), 1423-1429.

Bernardo, R. (2002). Breeding for quantitative traits in plants. Stemma Press. Woodbury, MN.

Blanche, S. B., Myers, G. O., Zumba, J. Z., Caldwell, D. W., \& Hayes, J. (2006). Stability comparisons between conventional and near-isogenic transgenic cotton cultivars. Journal of Cotton Science, 10, 17-28. 
Bradow, J. M., Davidonis, G. H. (2000). Quantification of fiber quality and the cotton production-processing interface: a physiologist's perspective. Journal of Cotton Science, 4, 34-64.

Campbell, B. T., \& Jones, M. A. (2005). Assessment of genotype x environment interactions for yield and fiber quality in cotton performance trials. Euphytica, 144, 69-78.

http://dx.doi.org/10.1007/s10681-005-4336-7.

Campbell, B. T., Chee, P. W., ..., \& Jones, D. C. (2012). Dissecting genotype $\times$ environment interactions and trait correlations present in the Pee Dee cotton germplasm collection following seventy years of plant breeding. Crop Science, 52, 690-699.

http://dx.doi.org/10.2135/cropsci2011.07.0380.

Ceccarelli, S. (1989). Wide adaptation: How wide? Euphytica, 40, 197-205.

http://dx.doi.org/10.1007/BF00024512.

Cotton Incorporated. (2016). Monthly economic letter. March 2016,

http://www.cottoninc.com/corporate/Market-Data/MonthlyEconomicLetter/ (April 6, 2016).

Davidonis, G. H., Johnson, A., Landivar, J. \& Hinojosa, O. (1996). Influence of low weight seeds and motes on the fiber properties of other cotton seeds. Field Crops Research, 48, 141-153. http://dx.doi.org/10.1016/S0378-4290(96)01018-0.

Eberhart, S. A., \& Russell, W. A. (1966). Stability parameters for comparing varieties. Crop Science, 6, 36-40. http://dx.doi.org/10.2135/cropsci1966.0011183X000600010011x.

Fan, X., Kang, M. S., ..., \& Xu., C. (2007). Yield stability of maize hybrids evaluated in multi-environment traits in Yunnan, China. Agronomy Journal, 99, 220-228. http://dx.doi.org/10.2134/agronj2006.0144.

Gauch, H. G. \& Zobel, R. W. (1997). Identifying mega-environments and targeting genotypes. Crop Science, 37, 311-326. http://dx.doi.org/10.2135/cropsci1997.0011183X003700020002x.

Gauch, H. G. (1992). Statistical analysis of regional yield trials: AMMI analysis of factorial designs. Elsevier, Amsterdam, the Netherlands.

Geng, S., Zhang, Q. F., \& Bassett, D. M. (1987). Stability in yield and fiber quality of California cotton. Crop Science, 27, 1004-1010.

http://dx.doi.org/10.2135/cropsci1987.0011183X002700050037x.

Gregory, K., Ng, E. H., ..., \& Hague, S. (2012). Fiber and yarn performance of upland cotton with improved fiber bundle strength. Crop Science, 52, 1-7.

http://dx.doi.org/10.2135/cropsci2011.08.0443.

Guillen-Portal, F. R., Russell, ..., \& Johnson, B. E. (2004). Selection environments for maize in the U.S. Western High Plains. Crop Science, 44, 1519-1526.

http://dx.doi.org/10.2135/cropsci2004.1519

Hake, K. D., \& Kerby, T. A. (1996). Cotton and the environment. in: Cotton Production Manual. S. Hake-Johnson, T. A. Kerby and K. D. Hake. eds., 3352, 324-334. University of 
California Division of Agriculture and Natural Resources.

Jost, P. (2005). Cotton fiber quality and the issues in Georgia. in: Cooperative Extension Service, 1-20. The University of Georgia, America

Kang, M. S. (2002). Quantitative genetics and plant breeding. CABI Publishing.

Kang, M. S. (2004). Breeding: Genotype-by-environment interaction. in: Encyclopedia of plant and crop science. R. M. Goodman eds., 218-221. Marcel-Dekker. New York:

Kang, M. S., Aggarwal, V. D., \& Chirwa, R. M. (2005). Adaptability and stability of bean cultivars as determined via yield-stability statistic and GGE biplot analysis. Journal of Crop Improvement, 15, 97-120. http://dx.doi.org/10.1300/J411v15n01_08.

Karademir, E., Karademir, C., Ekinci, R., \& Gencer, O. (2010). Relationship between Yield, Fiber Length and other Fiber-Related Traits in Advanced Cotton Strains. Notulae Botanicae Horti Agrobotanici Cluj-Napoca, 3(3), 111 - 116.

Kerby, T. A., Burgess, J., Bates, M., Albers, D., \& Lege, K. (2000). Partitioning variety and environmental contribution to variation in yield, plant growth, and fiber quality. in: Proc. Beltwide Cotton Conf., San Antonio, TX. 4-8 Jan. 2000. Natl. Cotton Counc. Am., Memphis, TN: 528-532.

Kothari, N., Dever, J., Hague, S., \& Hequet, E. (2015). Evaluating intraplant cotton fiber variability. Crop Science, 55, 564-570. http://dx.doi.org/10.2135/cropsci2014.01.0077.

Long, R., Bange, M., Delhom, C., Church, J., \& Constable, G. (2013). An assessment of alternative cotton fibre quality attributes and their relationship with yarn strength. Crop \& Pasture Science, 64, 750-762. http://dx.doi.org/10.1071/CP12382

May, O. L., \& Green C. C. (1994). Genetic variation for fiber properties in elite Pee Dee cotton population. Crop Science, 34, 684-690.

http://dx.doi.org/10.2135/cropsci1994.0011183X003400030016x.

McIntosh, M. S. (1983). Analysis of combined experiments. Agronomy Journal, 75, 153-155. http://dx.doi.org/10.2134/agronj1983.00021962007500010041x.

Mei, M., Syed, N. H., ..., \& Chen Z. J. (2004). Genetic mapping and QTL analysis of fiber-related traits in cotton (Gossypium) Theoretical and Applied Genetics, 108, 280-291. http://dx.doi.org/10.1007/s00122-003-1433-7.

Meredith, W. R .Jr, Boykin, D. L., ..., \& Zhang, J. (2012). Genotype x environment interactions over seven years for yield, yield components, fiber quality and gossypol traits in the regional high quality tests. Journal of Cotton Science, 16, 160-169.

Meredith, W. R. Jr. (2003). Thirty-six years of Regional High Quality Variety Tests. In: Proc. Beltwide Cotton Conf., Nashville TN. 6-10 Jan. 2003. Natl. Cotton Counc. Am., Memphis, TN: 2561-2563

Patsiali, S., Papastylianou, P., Travlos, I. S., \& Bilalis, D. J. (2014). Organic cropping system 
effects on fiber quality of three cotton cultivars in Greece. Agronomy Journal, 106, 1365-1370. http://dx.doi.org/10.2134/agronj13.0553.

Poehlman, J. M. \& Sleper, D. A. (1995). Breeding field crops. Iowa State Univ. Press.

Sequeira, R. A., Cochran, M., ..., \& Makela, M. E. (1994). Inclusion of plant structure and fiber quality into a distributed delay cotton model to improve management and optimize profit. Ecological Modelling, 71, 161-186.

http://dx.doi.org/10.1016/0304-3800(94)90080-9

Smith, C. W., Joy K., ..., \& Souder C. (2010). Fiber properties and mini-spun yarn performance of extra-long staple upland cotton. Journal of Cotton Science, 14, 82-90.

Snider, J. L., Collins, G. D., Whitaker, J., \& Davis, J. W. (2013). Quantifying genotypic and environmental contributions to yield and fiber quality in Georgia: Data from seven commercial cultivars and 33 yield environments. Journal of Cotton Science, 17, 285-292.

Steel, R. G. D., \& Torrie, H. 1980. Principles and procedures of statistics: A biometrical approach., 2nd ed. McGraw Hill Book Co., New York.

Ulloa, M. \& Meredith, W. R. (2000). Genetic linkage Map and QTL analysis of agronomic and fiber quality traits in an intraspecific population. Journal of Cotton Science, 4, 161-170.

Yan, W. K., \& Holland, J. B. (2010). A heritability-adjusted GGE biplot for test environment. Euphytica, 171, 355-369. http://dx.doi.org/10.1007/s10681-009-0030-5.

Yan, W. K., \& Kang, M. S. (2003). GGE biplot analysis: A graphical tool for breeders, geneticists, and agronomists. CRC Press, Boca Raton, FL.

Yan, W. K. (2001). GGE biplot - A windows application for graphical analysis of multi-environment trial data and other types of two-way data. Agronomy Journal, 93, 1111-1118. http://dx.doi.org/10.2134/agronj2001.9351111x.

Yan, W., Pageau, D., Frégeau-Reid, J., \& Durand, J. (2011). Assessing the representativeness and repeatability of test locations for genotype evaluation. Crop Science, 51, 1603-1610. http://dx.doi.org/10.2135/cropsci2011.01.0016.

Zhao, W. Q., Zhou, Z. G., ..., \& Wang, Y. H. (2013). Modeling fiber fineness, maturity and micronaire in cotton (Gossypium hirsutum L.). Journal of Integrative Agriculture, 12, 67-79. http://dx.doi.org/10.1016/S2095-3119(13)60206-3.

\section{Copyright Disclaimer}

Copyright for this article is retained by the author(s), with first publication rights granted to the journal.

This is an open-access article distributed under the terms and conditions of the Creative Commons Attribution license (http://creativecommons.org/licenses/by/4.0/). 